\title{
Correlation Between Body Mass Index and Risk of Obesity with Blood Pressure Women
}

\author{
$1^{\text {st }}$ Mariah Ulfah \\ Nursing Department \\ Harapan Bangsa University \\ Purwokerto, Indonesia \\ mariahulfah@uhb.ac.id
}

\author{
$2^{\text {nd }}$ Linda Yanti \\ Midwifery Faculty \\ Harapan Bangsa University \\ Purwokerto, Indonesia \\ lindayanti@uhb.ac.id
}

\author{
$3^{\text {rd }}$ Maya Safitri \\ Midwifery Faculty \\ Harapan Bangsa University \\ Purwokerto, Indonesia \\ mayasafitri@uhb.ac.id
}

\begin{abstract}
Obesity is one of the epidemic diseases in most developed countries. According to the WHO report states that more than 1.9 billion adults worldwide are overweight and more than 600 million people are obese, corresponding to $39 \%$ overweight and $13 \%$ obesity rates for the adult population in the world. Obesity has great side effects on health. Obesity is associated with increased mortality, BMI over 30 has a risk of death caused mainly by cardiovascular causes. The purpose of this study: to determine the correlation of BMI with the risk of obesity with Blood pressure women. The results showed that the chi-square test between BMI with the risk of obesity to systolic blood pressure was 0.021 where $p$ value $<0.05$. Then BMI risk of obesity to systolic blood pressure is 0.021 where $p$ value $<0.05$, so that means that there is a relationship between BMI risk of obesity with systolic and diastolic blood pressure.
\end{abstract}

Keywords: body mass index at risk of obesity, obesity, blood pressure

\section{INTRODUCTION}

Obesity is one of the epidemic diseases in most developed countries. According to the WHO report states that more than 1.9 billion adults worldwide are overweight and more than 600 million people are obese, corresponding to $39 \%$ overweight and $13 \%$ obesity rates for the adult population in the world [1] In the United States, 69\% of adults are overweight and $35 \%$ are obese. The increase in obesity continues to escalate into a global crisis because many cause serious chronic health conditions, including various forms of breast cancer which also show worse outcomes with obesity. These combined factors drive the 2013 American Medical Association's decision to recognize obesity as a disease. [2] . Obesity has great side effects on health. Obesity is associated with increased mortality, BMI over 30 has a risk of death caused mainly by cardiovascular causes. In addition, other risks are insulin resistance and type 2 diabetes mellitus, metabolic syndrome, disorders of the reproductive system, cardiovascular disease, pulmonary disease, gallstones (gallstones), bone, joint and skin diseases [3]. Obesity is at risk of dyslipidemia, hyperinsulinemia, coronary artery disease, cardiovascular disease, osteoarthritide, chronic renal failure and several cancers (for example, endometrial, esophageal, kidney cells, pancreatic, ovarian, breast, colon and rectal, thyroid and melanoma), as well as cancer (eg, endometrial, esophageal, kidney cells, pancreatic, ovarian, breast, colon and rectal, thyroid and melanoma). can cause cognitive

decline [4]

According to the results of basic health research in 2018 the level of obesity in adults in Indonesia increased to 21.8 percent [5]. This prevalence increased from the results of Riskesdas 2013 which states that the obesity rate in Indonesia only reached 14.8 percent. Obesity itself refers to conditions where the body mass index is above 27 . Likewise, the prevalence of excess body weight with a body mass index between 25 to 27 , also increased from 11.5 percent in 2013 to 13.6 percent in 2018 [6] Like hypertension, obesity is also a risk factor for degenerative diseases such as heart disease, stroke and other vascular diseases. Early detection of obesity is expected for all visits to primary care facilities. The number of visitors to the health center and its network (aged $>15$ years) in 2017 was reported to be $14,541,825$ people, of which the number of obesity examinations reported was 2,830,756 people or 19.47 percent, consisting of 1,210,498 men ( 17.98 percent) and 1,620,258 women (20.75 percent). From the measurement of obesity obtained by the percentage of obesity by 6.04 percent. the incidence of obesity in women is greater than in men. There are 4 districts / cities that do not report the results of obesity measurements, namely Sukoharjo, Karanganyar, Pati and Jepara. Regency / City with the highest percentage of obesity is Magelang City, which is 100 percent of the obesity checks. Regency / city with the lowest percentage of obesity is Kendal (0.05 percent), and Banyumas Regency is in the sequence 7 (13.6\%) [7] 


\section{RESULTS AND DiscUSSION}

Table 1. Characteristics of respondents Community Health Centers in Banyumas Regency. The health profile of the twins 2 health center in 2017 states that patients entering the age of more than 15 years with a total of 856 measured body mass index in women and stated that $100 \%$ are obese, this makes researchers interested to know the prevalence of obesity in 2018 .

\section{METHOD}

This research is included in the explanatory study (explanatory research), namely research conducted to explain the relationship between independent and bound variables through hypothesis testing. While the method used is a sample survey that is research that takes samples from a population using a questionnaire as a primary data collection tool. The approach used is cross sectional where the subject is only observed once and measurements are made on the character or variable of the subject at the time. population is all objects to be studied that have certain characteristics. Population in this study is mothers who measure obesity in the period of 2016 with secondary data, namely 856 samples using purposive sampling method with a minimum sampling calculation, the amount obtained is Determination the size of the sample using the formula of minimum sample size, i.e. [8]

$$
\begin{aligned}
=\mathrm{Z}_{2}{ }_{1-\alpha 2} \mathrm{P}(1-\mathrm{P}) \mathrm{N} \\
\mathrm{d}_{2} \stackrel{\mathrm{N}-1)+\mathrm{Z}_{2}{ }_{1-\alpha / 2} \mathrm{P}(1-\mathrm{P})}{ }
\end{aligned}
$$

Information:

$\mathrm{n}=$ minimum size

$\mathrm{N}=$ Number of population

$\mathrm{Z} 1-\alpha / 2=$ confidence level $(95 \%=1.96)$

$\mathrm{d}=$ precision (0.05) $9595 \%$ accuracy

$\mathrm{P}=$ target population proportion is $50 \%$ or

0.5

$1-\mathrm{P}=0.5$

Obesity sample calculation:

$\mathrm{n} \quad=1,962 \times 0.5 \times(1-0.5) \times 146$

n

$0,052(146-1)+1,962 \times 0,5 \times(1-0.5)$
$=140,2184$

$0.3625+0,9604=1,3229$

$=105.9$

\begin{tabular}{|c|c|c|c|}
\hline No & Variabel & $\mathrm{f}$ & $\%$ \\
\hline 1 & $\begin{array}{l}\text { Age } \\
\text { Late adulthood } \\
\text { Early elderly } \\
\text { Late elderly } \\
\text { old man }\end{array}$ & $\begin{array}{l}71 \\
15 \\
12 \\
8\end{array}$ & $\begin{array}{l}67 \\
14,2 \\
11,3 \\
7,5\end{array}$ \\
\hline 2 & $\begin{array}{l}\text { body mass index } \\
\text { Risky } \\
\text { Obesity } 1 \\
\text { Obesity } 2\end{array}$ & $\begin{array}{l}27 \\
48 \\
31\end{array}$ & $\begin{array}{l}25,5 \\
45,3 \\
29,2\end{array}$ \\
\hline 3 & $\begin{array}{l}\text { Blood pressure } \\
\text { Systolic } \\
\text { Normal } \\
\text { Pre hypertension First } \\
\text { degree } \\
\text { hypertension }\end{array}$ & $\begin{array}{l}46 \\
60 \\
6 \\
5\end{array}$ & $\begin{array}{l}39.3 \\
51.3 \\
5,1 \\
4,3\end{array}$ \\
\hline 4 & $\begin{array}{l}\text { 2nd degree } \\
\text { hypertension } \\
\text { Diastolic } \\
\text { Normal } \\
\text { Pre hypertension First } \\
\text { degree hypertension 2nd } \\
\text { degree hypertension }\end{array}$ & $\begin{array}{l}46 \\
60 \\
6 \\
5\end{array}$ & $\begin{array}{l}39.3 \\
51.3 \\
5,1 \\
4,3\end{array}$ \\
\hline
\end{tabular}

$=$ rounded to 106
Table 1 shows the age category seen in table 1 which is $67 \%$ most in late adulthood. Body mass index category is seen in table 4.4 , the largest is type 1 obesity, which is $45.3 \%$. While the blood pressure from table 1 shows that $51.3 \%$ of respondents experienced pre-hypertensive blood pressure both systolic and diastolic.

Table 2 correlation of Body Mass Index at Risk with Blood Pressure (Systolic and

Diastolic)

\begin{tabular}{|l|l|l|l|l|l|}
\hline BMI & \multicolumn{3}{|l|}{ Blood Pressure } & P \\
\hline & $\begin{array}{l}\text { Nor } \\
\text { mal }\end{array}$ & $\begin{array}{l}\text { Pre } \\
\text { Hyperte } \\
\text { nsion }\end{array}$ & $\begin{array}{l}\text { Hyperte } \\
\text { nsion } \\
\text { stage 1 }\end{array}$ & $\begin{array}{l}\text { Hype } \\
\text { rtens ion } \\
\text { stag e 2 }\end{array}$ & value \\
\hline $\begin{array}{l}\text { Obe sity } \\
\text { Risk }\end{array}$ & 19 & 9 & 1 & 2 & 0,021 \\
\cline { 1 - 4 } Obe sity 1 & 21 & 27 & 3 & 1 & \\
\hline Obe sity 2 & 6 & 24 & 2 & 2 & \\
\hline
\end{tabular}


From the cross tabulation table between risky body mass index and blood pressure, it is seen that the highest is Obesity level $1 \quad(26.7 \%)$ has hypertension, while $20.4 \%$ has Normal blood pressure and $17.4 \%$ who have 2 nd degree Obesity has prehypertension.

From the $p$ value it can be seen that the value is 0.021 , so that the $\mathrm{P}$ value $<0.05$, which means that Ho is rejected, so there is an influence between BMI at risk of blood pressure in elderly women. This is in line with research [9] that body mass index is closely related to systolic and diastolic blood pressure in men and women conducted in 3 groups. This is also consistent with Obesity research, this is due to fat can cause blockages in blood vessels so that it can increase blood pressure [10]. This study is in line with research in 22,354 Korean men and physiological disorder that occurs in regulation of blood flow causing hypertension are disorders of the cardiac output and peripheral resistance, interference with renninangiotensin system, and disorders of the autonomic nervous system to $31 \mathrm{~kg} / \mathrm{m} 2$ [11].

The estimated risk attributable to the Framingham Offspring Study of 2,027 men and 2,267 women aged 20 to 49 years followed for 8 years shows that obesity can cause $78 \%$ hypertension in men and $65 \%$ hypertension in women. There women, there is a relationship between body mass index and systolic and diastolic blood pressure in the range of body mass index 16 are several factors that cause hypertension, including genetic factors and environmental factors such as obesity, stress, excessive salt intake, smoking, and alcohol.

There is relationship between the onset of hypertension and hypertensive complications. During this long period, a series of changes occur in the cardiovascular system, including the cerebral circulation. Changes such as vascular remodeling, inflammation, oxidative stress and dysfunction baroreflex contribute to the pathogenesis of stroke caused by hypertension.

Changes in body fat for 8 years are associated with changes in systolic and diastolic blood pressure. Very obese women in the fourth decade had a 7fold increase in hypertension compared to thin women of the same age. The second Nurse Health Study was a prospective cohort study of 83,882 women aged 27 to 44 years with normal blood pressure followed for 14 years to 2005 for the incidence of hypertension. The strongest risk factor for developing hypertension is an increase in body mass index with obese women having an incidence of hypertension 4.7 times higher than women with a body mass index of less than $23.0 \mathrm{~kg} / \mathrm{m} 2$. In this study, $40 \%$ of new hypertension cases were associated with being overweight or obese, and
$50 \%$ of new hypertension cases were associated with a body mass index of $23 \mathrm{~kg} / \mathrm{m} 2$ or higher, recommendation for women with obese to implementing a healthy lifestyle with diet and exercise for balance always check the vital sign especially blood pressure. [12]

\section{CONCLUSION}

Conclusion in this research that age of respondent seen $67 \%$ most in late adulthood, the largest body mass index is obesity type 1 by $45.3 \%$, Blood pressure $51.3 \%$ of respondent's experience pre hypertensive blood pressure both systolic and diastolic and there is an influence of body mass index at risk of obesity on blood pressure in late adult women.

\section{REFERENCES}

[1] Y. C. Chooi, C. Ding, and F. Magkos, "The epidemiology of obesity," Metabolism., 2019.

[2] A. J. Dannenberg and N. A. Berger, Obesity, inflammation and cancer. 2013.

[3] S. Pal and V. Ellis, "The chronic effects of whey proteins on blood pressure, vascular function, and inflammatory markers in overweight individuals," Obesity, 2010.

[4] N. Y. Krakauer and J. C. Krakauer, "A new body shape index predicts mortality hazard independently of body mass index," PLoS One, vol. 7, no. 7, 2012.

[5] Depkes RI, Pedoman Pencegahan Dan Penanggulangan Kegemukan Dan Obesitas pada Anak Sekolah.

2012.

[6] S. Wang, Y. Liu, F. Li, H. Jia, L. Liu, and F. Xue, "A novel quantitative body shape score for detecting association between obesity and hypertension in China," $B M C$ Public Health, vol. 15, no. 1, pp. 1-9, 2015.

[7] Central Java Province Health Office, "Profil Kesehatan Provinsi Jawa 
Tengah 2017," Dinkes Jateng, vol. 3511351, no. 24, pp. 1-62, 2017.

[8] A. Hidayat, "Menghitung Besar Sampel Penelitian," Metodologi, p. $1,2012$.

[9] L. M. Gerber and P. M. Stern, "Relationship of body size and body mass to blood pressure: sex-specific and developmental influences.," Hum. Biol., vol. 71, no. 4, pp. 505-28, 1999.

[10] D. M. Kiki Korneliani, "Obesitas Dan Stress Dengan Kejadian Hipertensi,"
KESMAS - J. Kesehat. Masy., vol. 7, no. 2, pp. 117-121, 2012.

[11] L. Klimek et al., "Visual analogue scales ( VAS ): Measuring instruments for the documentation of symptoms and therapy monitoring in cases of allergic rhinitis in everyday health care Position Paper of the German Society of Allergology ( AeDA ) and the German Society of All," Allergo J. Int., vol. 26, no. 1, pp. 16-24, 2017.

[12] W. S. Aronow, "Association of obesity with hypertension," Ann. Transl. Med., vol. 5, no. 17, pp. 11- 13, 2017 